\title{
Upaya Meningkatkan Kemampuan Berpikir Kritis Mahasiswa Melalui Pembelajaran Discovery Learning Berbasis Assessment Learning
}

\author{
${ }^{1}$ Eric Dwi Putra, ${ }^{2}$ Ria Amalia \\ 1,2Program Studi Pendidikan Matematika, FPMIPA, IKIP PGRI Jember Indonesia \\ 2Email:87ria.amalia@gmail.com
}

\begin{abstract}
Improved learning will continue to be done to continuously improve the quality of learning. One of the efforts made through discovery learning is based on assessment learning. Collaborating between discovery learning and assessment learning is expected to improve students' critical thinking skills in discrete mathematics courses. Classroom action research conducted in 2 cycles where each cycle carried out as many as 4 (four) meetings. The results showed that a) Implementation of discovery learning based on assessment learning that can improve students' critical thinking skills is carried out in 7 stages, namely stimulation, problem statement, data collection, data processing, verification, generalization and peer assessment. The seven stages work together to create independent learning and train students' thinking skills. b) Students' critical thinking skills have increased by $33.33 \%$. This percentage indicates that discovery learning based on assessment learning can improve students' critical thinking skills.
\end{abstract}

Keyword: discovery learning, assessment learning, critical thinking

\begin{abstract}
Abstrak: Perbaikan pembelajaran akan terus dilakukan untuk senantiasa meningkatkan kualitas pembelajaran. Salah satu upaya yang dilakukan melalui pembelajaran discovery learning berbasis assessment learning. Dengan mengkolaborasikan antara discovery learning dan assessment learning diharapkan dapat meningkatkan kemampuan berpikir kritis mahasiswa pada mata kuliah matematika diskrit. Penelitian tindakan kelas yang dilakukan dalam 2 siklus dimana masingmasing siklus dilaksanakan sebanyak 4 (empat) pertemuan. Hasil penelitian menunjukkan bahwa a) Implementasi pembelajaran discovery learning berbasis assessment learning yang dapat meningkatkan Kemampuan Berpikir kritis mahasiswa dilakukan dalam 7 tahapan yaitu Stimulation, problem statement, data collection, data processing, Verification, generalization serta peer Assessment. Ketujuh tahapan tersebut saling bersinergi dalam mewujudkan pembelajaran yang mandiri dan melatih kemampuan berpikir mahasiswa. b) Kemampuan berpikir kritis mahasiswa mengalami peningkatan sebesar 33,33\%. Prosentase tersebut mengindikasikan bahwa pembelajaran discovery learning berbasis assessment learning dapat meningkatkan Kemampuan Berpikir kritis mahasiswa.
\end{abstract}

Kata Kunci: discovery Learning, assessment learning, berpikir kritis

\section{PENDAHULUAN}

Pendidikan merupakan aktifitas serta usaha manusia agar dapat meningkatkan kepribadian dengan cara membina potensi-potensi di dalam pribadinya, yaitu rohani (rasa, karsa, pikir, budi nurani, cipta) dan jasmani (panca indera serta keterampilan keterampilan). Oleh karena itu, pendidikan sangat penting dikarenakan dapat mengubah bentuk karakter setiap individu serta mengubah sikap. Hal tersebut juga sesuai dengan tujuan dari pendidikan nasional yaitu untuk dapat mencerdaskan kehidupan bangsa. Untuk mencapai dari tujuan pendidikan nasional tersebut maka pemerintah selalu mengadakan perbaikan-perbaikan yang salah satunya yaitu memperbaiki kurikulum. Selain itu juga, guru ataupun dosen juga harus mempunyai kualitas untuk 
mengembangkan daya nalar kepada siswa/mahasiswa. Salah satu mata pelajaran yang dapat membuat mahasiswa bernalar yaitu matematika.

Pengembangan penalaran di dalam pembelajaran matematika akan terjadi jika mahasiswa diajak berpikir atau membangun terhadap pemahaman konsep materi perkuliahan yang dipelajari. Kilpatrick (1985) mengemukakan bahwa peserta didik yang mempunyai keterampilan procedural dan konseptual, tidak dijamin mampu menyelesaikan masalah. Adam dan Hamm (Wijaya ,2012:5-6) berpendapat bahwa matematika mempunyai peran sebagai cara berpikir, maka dapat dikatakan kemampuan berpikir/bernalar merupakan potensi yang wajib dimiliki mahasiswa. Karena pelajaran matematika menekankan kepada kemampuan bernalar mahasiswa, maka berpikir kritis (critical thinking) yang termasuk salah satu dari tingkatan berpikir (Soedjadi, 2007:21),bisa dikembangkan di dalam proses pembelajaran matematika pada mahasiswa. Ennis (2000:23) berpendapat bahwa berpikir kritis adalah kemampuan esensial yang wajib dimiliki mahasiswa untuk menyelesaikan masalah serta mengambil keputusan yang baik dan benar. Oleh karena itu, pembelajaran matematika akan sangat cocok untuk melatih proses berpikir pada mahasiswa.

Berpikir kritis saat ini sudah menjadi kompetensi untuk tujuan pendidikan pada perguruan tinggi. Oleh karena itu, berpikir kritis pada pendidikan tinggi merupakan salah satu kompetensi yang wajib dicapai dan alat yang dibutuhkan untuk mengkonstruksi pengetahuan mahasiswa. Supaya mahasiswa dapat memenuhi kompetensi tersebut maka dosen perlu memberikan kepada mahasiswa suatu pembelajaran yang membuat mahasiswa aktif serta mengarah terhadap kemampuan dalam memahami konsep serta berpikir kritis maupun berpikir tingkat tinggi, dan didasarkan pada belajar bermakna yang berhubungan dengan konteks lingkungan mahasiswa (Ahern-Rindell, dan Tishman et all dalam Bagus, 2004). Untuk meningkatkan keterampilan berpikir kritis serta pemahaman konsep maka dosen harus membuat perkuliahan yang berkualitas. Proses berpikir kritis bisa dikembangkan di dalam pembelajaran matematika kepada mahasiswa jika proses pembelajaran matematika lebih ditekankan kepada suatu masalah, sehingga siswa akan terlatih untuk pemecahan masalah.

Di dalam pembelajaran matematika, pencapaian pemahaman konsep serta keterampilan berpikir kritis akan sangat berharga jika hanya dibandingkan dengan prestasi belajar yang hanya diperoleh dengan skor tes akhir belajar dan hal tersebut hanya berorientasi kepada proses mahasiswa untuk menghafal (Brooks \& Brooks, 1993). Tetapi dalam dunia nyata, proses pembelajaran yang terjadi di kampus masih berorientasi kepada pembelajaran menghafal. Perkuliahan masih didominasi oleh dosen sedangkan mahasiswa lebih sering untuk bersifat pasif.

Matematika diskrit merupakan mata kuliah wajib yang harus ditempuh oleh mahasiswa prodi pendidikan matematika IKIP PGRI Jember. Mata kuliah matematika diskrit masih dianggap mata kuliah yang sulit karena memerlukan perhitungan yang rumit. Sehingga dosen pengampu matematika diskrit harus mampu memotivasi mahasiswanya bahwa mata kuliah ini akan mendukung pengetahuan mereka untuk materi kuliah yang lain. Proses pembelajaran Mata kuliah Matematika diskrit selama ini masih dilakukan dengan proses pembelajaran ceramah. Sehingga mahasiswa fokus untuk mendengarkan materi yang diberikan oleh dosen. Dengan proses pembelajaran yang dilakukan dengan sistem ceramah maka mahasiswa hanya berada pada level menghafal dan masih tergolong pada tingkat pengetahuan yang rendah (Raka, 2005). Proses perkuliahan hanya sebatas dosen meneruskan informasi kepada mahasiswa dan selanjutnya mahasiswa menghafal materi. Dengan mahasiswa hanya menghafal, maka yang terjadi yaitu jika memperoleh permasalahan yang berbeda dan sifatnya baru maka mahasiswa akan mengalami kesulitan karena penguasaan konsep yang dimiliki oleh 
mahasiswa sangat rendah. Mahasiswa tidak mampu untuk berpikir bernalar dan berpikir kritis untuk menyelesaikan permasalahan-permasalahan yang baru. Dengan permasalahan tersebut, dosen perlu menerapkan model pembelajaran yang berbasis pada penyelesaian pemecahan masalah sehingga mahasiswa bisa meningkatkan tentang pemahaman konseptual serta keterampilan berpikir kritis terhadap mata kuliah matematika diskrit. Salah satu dari model pembelajaran yang dapat meningkatkan pemahaman konseptual dan berpikir kritis yaitu model pembelajaran discovery learning.

Model Pembelajaran discovery merupakan model pembelajaran yang bisa melatih mahasiswa untuk aktif. Model pembelajaran discovery mengajarkan kepada mahasiswa untuk memahami konsep sehingga mahasiswa tidah hanya menghafal banyak rumus. Hal ini sangat sesuai dengan pendapat Carin dan Sund (1985) yang berpendapat bahwa discovery merupakan suatu proses mental di mana individu mengasimilasi konsepkonsep serta prinsip-prinsip. Pengajaran dengan Discovery diharapkan siswa benar-benar akan aktif belajar menemukan bahan yang dipelajarinya dengan sendirinya sehingga akan lebih bermakna. Dengan pembelajaran Discovery (penemuan) hal-hal yang baru untuk siswa yang diharapkan bisa ditemukannya itu dapat berupa konsep, rumus ,teorema, aturan,pola,serta jenis lainnya (Suherman, 2001). Senada dengan hal tersebut Ausubel (1963) juga berpendapat bahwa discovery tampaknya metode yang paling baik karena sudah dibandingkan dengan belajar hafalan. Discoverylearningyaitu model pembelajaran yang dikondisikan sedemikian rupa agar anak mendapatkan pengetahuan yang sebelumnya masih belum diketahui oleh mahasiswa dengan tidak adanya pemberitahuan, dimana seluruah atau sebagian pengetahuan ditemukan sendiri oleh mahasiswa.

Selain dosen menerapkan model pembelajaran yang tepat, didalam pelaksanaan proses pembelajaran didalam kelas juga tidak akan terlepas dari bentuk assessment (penilaian). Penilaian adalah bagian penting yang sulit terpisahkan didalam sistem pendidikan. Salah satu bentuk penilaian yang telah dikembangkan oleh beberapa pakar yaitu diantaranya Assessment for Learning. Assessment for Learning adalah bentuk sebuah penilaian yang dalam prosesnyadengan mencari dan menafsirkan bukti ataupun informasi yang dipakai mahasiswaserta dosensupaya mengetahui sejauh mana mahasiswapaham terhadap pembelajaran yang telah dilaksanakan, indikator apa yang wajib dicapai oleh mahasiswaserta bagaimana cara terbaik yang wajib mahasiswa lakukan untuk mencapai indikator tersebut. Dengan menerapkan Assessment for Learning diharapkan mahasiswa bisa memperhatikan serta mengontrol apa yang telah dikerjakan mereka sendiri, dan bisa meningkatkan dari kualitas pembelajaran yang telah dilakukan. Assesment for Learning mempunyai tujuan diantaranya untuk melakukan perbaikan didalam proses pembelajaran serta juga menciptakan proses pembelajaranefektif yang sesuai kebutuhan mahasiswa.

Beberapa penelitian terdahulu menunjukkan bahwa pembelajaran yang menerapkan model pembelajaran discovery bisa mengoptimalkan hasil belajar mahasiswa. Misalnya yaitu Rohaumah (2018: 36) di dalam hasil penelitiannya menjelaskan bahwa ada pengaruh menggunakan model pembelajaran discovery learning terhadap kemampuan berpikir kritis, selain itu juga menjelaskan bahwa hasil tes serta observasi kelas yang memakai discovery learning lebih baik daripada kelas yang menggunakan metode konvensional. Rahayu, dkk (2019:8) mengemukakan dengan memakai model pembelajaran discovery learning bisa meningkatkan berpikir kritis peserta didik.

Dengan beberapa permasalahan diatas, maka peneliti dirasa perlu untuk melakukan penelitian. Dalam penelitian ini, diharapkan dapat memperbaiki berpikir kritis mahasiswa sehingga mahasiswa dapat bernalar dan memahami konsep dengan baik dan juga dapat menyelesaikan soal berbasis masalah. Berdasarkan permasalahan, 
penulis melakukan penelitian yang berjudul "Upaya Meningkatkan Berpikir Kritis Mahasiswa Melalui Pembelajaran Discovery Learning Berbasis Assessment Learning". Rumusan masalah dalam penelitian ini adalah: 1) Bagaimana implementasi pembelajaran discovery learning berbasis assessment learning yang bisa meningkatkan Kemampuan Berpikir kritis mahasiswa?, dan 2) Bagaimana peningkatan kemampuan berpikir kritis mahasiswa sesudah diterapkan dengan Pembelajaran Discovery Learning Berbasis Assessment Learning?

\section{METODE}

Dalam penelitian ini menggunakan pendekatan kualitatif. Penelitian kualitatif merupakan penelitian dengan maksud agar dapat memahami fenomena tentang semua yang tampak pada subjek penelitian misalnya persepsi, motivasi, perilaku tindakan, dll., secara holistic disertai dengan cara mendeskripsikan ke dalam bentuk kata-kata serta bahasa, pada konteks khusus yang bersifat alamiah serta memanfaatkan bermacammacam metode ilmiah (Moleong, 2014: 6). Data yang akan dikumpulkan bersifat deskriptif, yaitu berupa penjabaran pembelajaran discovery learning berbasis Assessment Learning yang dapat meningkatkan berpikir kritis mahasiswa.

Di dalam Penelitian ini memakai jenis penelitian tindakan kelas. Penelitian tindakan kelas (PTK) dimulai dari suatu permasalahan yang ada di dalam pembelajaran serta terjadi setiap hari yang diperoleh oleh dosen maupun mahasiswa. Kunandar (2008: 45) menjelaskan bahwa penelitian tindakan yang berkaitan dengan bidang pendidikan dan dilaksanakan yang mempunyai tujuan memperbaiki mutu praktik pembelajaran di kelas maka penelitian tersebut disebut PTK. Dipilihnya jenis penelitian ini dikarenakan mempunyai tujuan yang sesuai dengan karakteristik PTK, yaitu akan melakukan perbaikan terhadap proses pembelajaran pada materi matematika diskrit dengan model pembelajaran discovery learning berbasis Assessment Learning sehingga dapat meningkatkan berpikir kritis terhadap mahasiswa.

Langkah-langkah dalam penelitian sesuai dengan model Kemmis dan Mc Taggart. Langkah-langkah berbentuk spiral yang berupa suatu siklus serta terdapat empat tahap, diantaranya: perencanaan (plan), pelaksanaan (action), pengamatan (observation), serta yang terakhir refleksi (reflection). Untuk pelaksanaan siklus di dalam penelitian dilakukan sebanyak 2 siklus yang masing-masing siklus dilaksanakan sebanyak 4 (empat) pertemuan. Setiap akhir siklus dilakukan satu kali tes akhir sehingga terdapat dua kali tes selama dua siklus. Subjek dalam penelitian merupakan mahasiswa pada semester 5 tahun akademik 2018/2019 yang sedang mengikuti mata kuliah matematika diskrit. Instrumen yang dipakai di dalam penelitian antara lain: soal tes, catatan lapangan, lembar keaktifan dosen, lembar keaktifan mahasiswa, serta Lembar kegiatan mahasiswa.

Kriteria keberhasilan yang digunakan dalam PTK ini yaitu: a) Proses pembelajaran (aktifitas dosen dan aktifitas mahasiswa) dalam kategori Baik, b) Kemampuan Berpikir Kritis dikatakan meningkat jika minimal terdapat $75 \%$ mahasiswa yang memperoleh nilai B.

\section{HASIL DAN PEMBAHASAN}

Proses implementasi pembelajaran discovery learning berbasis assessment learning pada mata kuliah matematika diskrit termasuk dalam kategori metode penemuan terbimbing. Hal ini dilakukan dengan pertimbangan bahwa a) penemuan murni membutuhkan waktu yang lebih lama daripada penemuan terbimbing, b) metode ini dilakukan pada kelas kecil sehingga dapat memaksimalkan bimbingan dosen terhadap mahasiswa.

Proses penemuan, pada pembelajaran discovery learning berbasis assessment learning secara teknis dilakukan melalui diskusi kelompok. Hal ini dilakukan guna efisiensi waktu pembelajaran serta melatih kemandirian dalam belajar mahasiswa. Kemandirian yang 
dibangun pada tahap Stimulation, problem statement, data collection, data processing, verification, generalization serta assessment. sebagaimana pendapat Wulandari (2016:228) bahwa kolaborasi antara discovery learning dan assessment learning mampu mewujudkan kemandirian belajar peserta didik.

Assessment yang dilakukan di dalam penelitian yaitu peer assessment. Mahasiswa diberi kebebasan untuk memberikan komentar atau memberikan penilaian terhadap pekerjaan mahasiswa lain. Selanjutnya hasil diskusi kelompok tersebut mereka jadikan bahan sharing antar kelompok lain. Dengan begitu pendidik memberikan kesempatan mahasiswa untuk mengevaluasi hasil diskusi/laporan nya. Hal ini didukung oleh Sutawidjaja (2002:358) yang berpendapat bahwa ketika kelompok menyajikan dari hasil laporan/diskusinya (benar atau salah), kelompok tersebut mempunyai kesempatan yang berharga untuk melakukan perbaikan hasil diskusi/laporan mereka.

Hasil pengamatan/observasi yang dilakukan dalam penelitian ini mengenai proses pembelajaran didapat data sebagai berikut.

Tabel 1. Rekapitulasi Hasil Observasi terhadap Proses Pembelajaran Discovery Learning berbasis Assessment Learning

\begin{tabular}{llll}
\hline Skor Prosentase & Siklus I & Siklus II & Ket \\
\hline Aktifitas Mahasiswa & $82 \%$ & $89 \%$ & Baik \\
Aktifitas Dosen & $86,67 \%$ & $93,33 \%$ & Sangat Baik \\
\hline
\end{tabular}

Berdasarkan hasil dari observasi tersebut, maka diperoleh informasi bahwa proses pembelajaran discovery learning berbasis assessment learning pada mata kuliah matematika diskrit berjalan baik dan telah memenuhi kriteria dalam penelitian ini.

Kemampuan berpikir kritis mahasiswa diukur menggunakan Tes akhir siklus dan pemberian tugas pada setiap pertemuan. kemudian skor tersebut dikategorikan seperti berikut.

Tabel 2. Pengkategorian Kemampuan Berpikir Kritis.

\begin{tabular}{cc}
\hline Rata-rata Skor Kemampuan Berpikir & Keterangan \\
Kritis & \\
\hline $80<K B K \leq 100$ & $\mathrm{~A}$ \\
$69<K B K \leq 80$ & $\mathrm{~B}$ \\
$55<K B K \leq 69$ & $\mathrm{C}$ \\
$44<K B K \leq 55$ & $\mathrm{D}$ \\
$0<K B K \leq 44$ & $\mathrm{E}$ \\
\hline
\end{tabular}

Dari pengambilan data tentang kemampuan berpikir kritis mahasiswa, diperoleh informasi seperti di bawah ini.

Tabel 3. Rekapitulasi Data Kemampuan Berpikir Kritis Mahasiswa

\begin{tabular}{lcc} 
Prosentase Kemampuan Berpikir Kritis & Siklus 1 & Siklus II \\
\cline { 2 - 3 } & $50 \%$ & $83,33 \%$ \\
\hline
\end{tabular}

Informasi dari tabel 3, sebanyak 50\% mahasiswa di siklus 1 yang telah mampu memperoleh minimal nilai B. Dengan kata lain kemampuan berpikir kritis mahasiswa pada siklus 1 belum memenuhi kriteria keberhasilan yang telah ditetapkan dalam penelitian ini. akan tetapi, hasil yang berbeda diperoleh pada siklus II yaitu sebanyak $83,33 \%$ mahasiswa yang memperoleh minimal B. Dengan demikian, dapat dikatakan bahwa kemampuan berpikir kritis mahasiswa meningkat dan memenuhi kriteria keberhasilan penelitian ini. 
Selain itu, berkenaan dengan kemampuan berpikir kritis mahasiswa ketika menyelesaikan soal tentang matematika diskrit didapatkan informasi bahwa masih ada mahasiswa yang belum memahami konsep-konsep dasar/prasyarat. hal ini didukung dari hasil pekerjaan yang menunjukkan indikasi tersebut.

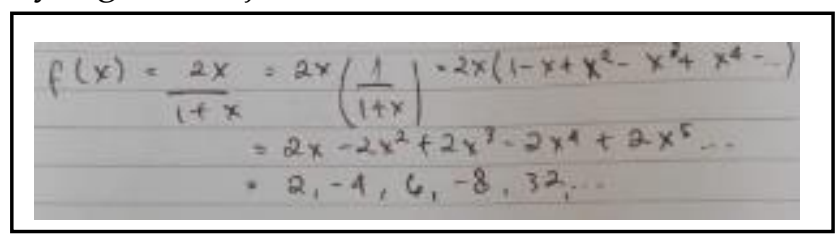

Gambar 1. Hasil Pekerjaan Mahasiswa A

Gambar 1. merupakan hasil pekerjaan mahasiswa A ketika menyelesaikan permasalahan mengenai fungsi pembangkit. dalam permasalahan tersebut, mahasiswa diminta untuk mencari barisan yang dibangkitkan dari suatu fungsi yang telah ditentukan. hasil pekerjaan di atas menunjukkan bahwa barisan yang diperoleh berasal dari hasil perkalian dari koefisien dan perpangkatan. Setelah dilakukan terhadap mahasiswa yang bersangkutan, hal ini terkonfirmasi dengan baik yaitu mahasiswa melakukan operasi perkalian antara koefisien $x$ dengan nilai pangkatnya. Dengan demikian terjadi kesalahan konsep/miskosepsi terhadap tahap tersebut. Berikut ini hasil pekerjaan mahasiswa setelah diminta untuk memperbaiki.

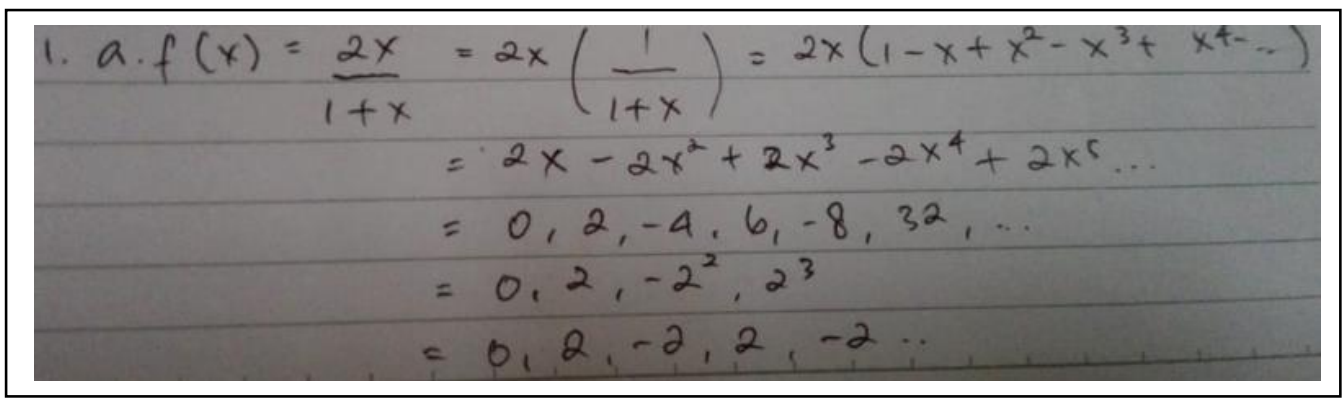

Gambar 2. Hasil Revisi Pekerjaan Mahasiswa A

Hasil revisi perbaikan tersebut, belum juga menunjukkan jawaban yang benar, mahasiswa masih melakukan kesalahan dalam mengubah bentuk dari persamaan menjadi barisan. Tentu saja, akan menjadi perhatian peneliti untuk lebih memperdalam penyebab miskonsepsi dan perlu untuk dilakukan tindakan guna perbaikan focus pembelajaran selanjutnya.

Dari proses pembelajaran dan kemampuan berpikir mahasiswa yang menjadi focus di dalam penelitian ini maka bisa diketahui bahwa implementasi pembelajaran discovery learning berbasis assessment learning pada mata kuliah matematika diskrit mampu meningkatkan kemampuan berpikir kritis mahasiswa. Adanya peningkatan kemampuan berpikir kritis mahasiswa disebabkan oleh kecocokan model pembelajaran yang digunakan. Keterampilan berpikir kritis dapat dilatih melalui pembelajaran discovery learning berbasis assessment learning Karena adanya kesesuaian antara tahapan pembelajaran dengan indikasi keterampilan berpikir kritis menurut Lai (2011) bahwa keterampilan berpikir kritis dapat diamati ketika mahasiswa menganalisis argument, membuat inferensi, melakukan evaluasi serta membuat keputusan. Seluruh kegiatan tersebut dapat dimunculkan saat pembelajaran discovery learning berbasis assessment learning.

Disamping itu, terdapat kendala dalam penelitian beserta alternative solusinya akan dipaparkan seperti di bawah ini. 
Tabel 4. Kendala Penelitian dan Alternatif Solusi

\begin{tabular}{lll}
\hline \multicolumn{1}{c}{ Kendala Penelitian } & \multicolumn{1}{c}{ Alternatif Solusi } \\
\hline 1. $\begin{array}{l}\text { Penugasan yang diberikan saat untuk } \\
\text { proses penemuan masih terlalu sulit } \\
\text { bagi mahasiswa. sehingga }\end{array}$ & 1. & $\begin{array}{l}\text { Perlu desain tugas dengan tingkat } \\
\text { kesulitan bertahap dan disesuaikan } \\
\text { dengan waktu pembelajaran. }\end{array}$ \\
$\begin{array}{l}\text { memerlukan waktu cukup lama. } \\
\text { 2. Mahasiswa terlihat bosan dan kurang } \\
\text { serius apabila diminta untuk } \\
\text { melakukan peer assessment secara } \\
\text { terus menerus. }\end{array}$ & 2. & $\begin{array}{l}\text { Butuh variasi tentang pelaksanaan } \\
\text { assessment di setiap pertemuannya. }\end{array}$ \\
3. $\begin{array}{l}\text { Komentar/umpan balik yang } \\
\text { diberikan oleh mahasiswa ke } \\
\text { kelompok lain cenderung bersifat } \\
\text { negatif }\end{array}$ & 3. $\begin{array}{l}\text { Perlu adanya pemberian informasi } \\
\text { yang positif tentang komentar/umpan } \\
\text { balik yang dilakukan. }\end{array}$ \\
\hline
\end{tabular}

\section{SIMPULAN}

Kesimpulan dari hasil penelitian ini yaitu a) Implementasi pembelajaran discovery learning berbasis assessment learning yang dapat meningkatkan Kemampuan Berpikir kritis mahasiswa dilakukan dalam 7 tahapan yaitu Stimulation, problem statement, data collection, data processing, verification, generalization serta peer assessment. Ketujuh tahapan tersebut saling bersinergi dalam mewujudkan pembelajaran yang mandiri dan melatih kemampuan berpikir mahasiswa. b) Kemampuan berpikir kritis mahasiswa terjadi peningkatan sebesar 33,33\%. Prosentase tersebut mengindikasikan bahwa pembelajaran discovery learning berbasis assessment learning bisa meningkatkan kemampuan berpikir kritis mahasiswa.

\section{UCAPAN TERIMA KASIH}

Ucapan terima kasih penulis ucapkan kepada seluruh pihak yang turut membantu dalam menyelesaikan penelitian ini seperti IKIP PGRI Jember

\section{DAFTAR PUSTAKA}

Ausubel, D.P. (1963). Some Psychological and Educational Limitations of Learning by Discovery. New York State. Mathematics Teacher Journal. XIII. 90-108.

Bagus Putu. A, Ida. (2004). Pengembangan Perangkat Model Belajar Berdasarkan Masalah Dipandu Strategi Kooperatif Serta Pengarug Implementasinya Terhadap Kemampuan Berpikir Kritis Dan Hasil Belajar Siswa Sekolah Menengah Atas Pada Pelajaran Ekosistem, Disertasi, Malang: PPS-UM Malang, tidak diterbitkan.

Brooks, J.G dan Brooks, M.G. (1993). In Search of Understanding The case For Contructivist Classrooms. Alexandria, VA: Association for Supervision and Curriculum Development.

Carin A. Arthur \& Sund B. Robert. (1985). Teaching Science Through Discovery. Merrill Publishing Company: Columbus.

Ennis, Robert H. (2000). An Outline Of Goals For Critical Thinking Curuculum and Its Assesment. (Online). http://facullty.ed.uiue.edu/rhennis. diakses tanggal 18 Juli 2014.

Kilpatrick,J. (1985). Reflection adnd Recursion. Educational Studies in Mathematics, 16.

Kunandar. (2008). Langkah-Langkah Penelitian Tindakan Kelas Sebagai Pengembangan Profesi Guru. Jakarta: PT Raja Grafindo Persada.

Moleong, L. (2014). Metode Penelitian Kualitatif. Bandung: PT Remaja Rosdakarya. 
Lai, E.R. (2011). Critical Thinking: a literature review (research report). Pearson: Always Learning downloaded Desember 15, 2018 from: http://images.pearsonasessments.com/images/tmrs/criticalthinkingreviewfinal. pdf.

Raka Joni, T, (2005), Pembelajaran yang mendidik, Artikulasi Konseptual, Terapan Konseptual, dan Verifikasi Empirik, Malang: PPS UM.

Rahayu, dkk. (2019). Peningkatan Keterampilan Berpikir Kritis dan Hasil Belajar Siswa Kelas 4 SD melalui Model Pembelajaran Discovery Learning. Jurnal Pendidikan Dasar Indonesia. Vol 4.No.1. p 8-13.

Rohaumah, C. (2018). Pengaruh Metode Pembelajaran Discovery Learning Terhadap Kemampuan Berpikir Kritis Siswa Dalam Pembelajaran Matematika. Jurnal Gammath. Vol. 3 No. 1. 28- 37.

Suherman,E, dkk. (2001). Common Text Book Strategi Pembelajaran Matematika Kontemporer. Bandung: JICA-UPI.

Soedjadi, R. (2007). Masalah Kontekstual Sebagai Batu Sendi Matematika Sekolah. Surabaya: Unesa Pusat Sains dan Matematika Sekolah

Sutawidjaja, A. (2002). Konstruktivisme Konsep dan Implikasinya pada Pembelajaran Matematika. Jurnal Matematika atau Pembelajarannya. VIII (Edisi Khusus):355-359

Wijaya, Ariyadi. (2012). Pendidikan Matematika Realistik Suatu Alternatif Pendekatan Pembelajaran Matematika. Yogyakarta: Graha Ilmu.

Wulandari, Setyaji Puji. (2016). Menciptakan Kemandirian Belajar melalui Pembelajaran Berbasis Discovery Learning dengan Asesment for Learning. Prosiding Seminar Nasional Matematika. Universitas Negeri Semarang. ISSN. 2613-9189. 